\title{
Developing a Local Instruction Theory for Learning the Concept of Angle through Visual Field Activities and Spatial Representations
}

\author{
Bustang $^{1}$, Zulkardi $^{2}$, Darmawijoyo ${ }^{2}$, Maarten Dolk ${ }^{3} \&$ Dolly van Eerde ${ }^{3}$ \\ ${ }^{1}$ Graduate student of International Master Program on Mathematics Education Sriwijaya University, Indonesia \\ in collaboration with Utrecht University, The Netherlands \\ ${ }^{2}$ Faculty of Teacher Training and Education, Sriwijaya University, Indonesia \\ ${ }^{3}$ Freudenthal Institute for Science and Mathematics Education, Utrecht University, The Netherlands \\ Correspondence: Bustang, International Master Program on Mathematics Education Sriwijaya University, \\ Indonesia. E-mail: b.bustang@gmail.com
}

\author{
Received: June 5, 2013 Accepted: July 5, 2013 Online Published: July 18, 2013 \\ doi:10.5539/ies.v6n8p58 URL: http://dx.doi.org/10.5539/ies.v6n8p58
}

\begin{abstract}
This paper reports a study on designing and testing an instructional sequence for the teaching and learning of the concept of angle in Indonesian primary schools. The study's context is employing the current reform movement adopting Pendidikan Matematika Realistik Indonesia (an Indonesian version of Realistic Mathematics Education). Using a design research approach, a hypothetical learning trajectory was developed and a set of activities was performed to gain a better understanding of how the third grade students' (aged $8-9$ years) understanding of the concept of angle may be fostered. Theoretical development is driven by an iterative process of designing instructional activities, performing teaching experiments and conducting retrospective analysis in order to contribute to local instruction theory on the concept of angle. The concept of angle emerged and evolved during long term classroom activities of visual field activities involving vision and spatial representations. Classroom events were recorded, group works were video-taped and student materials were collected. Qualitative analysis of a teaching experiment showed that by conducting the visual field activities involving vision and constructing spatial representations, students could develop their understanding of the concept of angle as well as their initial understanding of the notion of vision lines and blind spots.
\end{abstract}

Keywords: angle concept, local instruction theory, visual field activities, spatial representations, RME, HLT

\section{Introduction}

The discussion about the nature of the concept of angle has been carried out for more than two thousand years and the debate is not over yet (Matos, 1990). Accordingly, there are many different definitions of angle during the course of history which vary significantly in their emphases (Keiser, 2004). There is no single definition of the concept of angle that all mathematicians and mathematics didacticians agree on. Mitchelmore and White (2000) called this peculiarity the multifaceted nature of the concept of angle in which each facet has different meanings depending on the physical and mathematical situations at hand.

Researchers over the past decade or so have noted that there are various definitions of angle that originated from many different perspectives. Several authors found a wide variety of the definition of angle in the school mathematics textbooks (Strehl, 1983; Close, 1982; \& Krainer, 1989; as cited in Mitchelmore \& White, 1998). Mitchelmore and White (2000) noted that there are three broad categories of definitions of angle that occur repeatedly: viewing angle either as a measure of turning between two lines meeting at a point, as a pair of rays that extend from a common point, or as a region bounded by the intersection of two half-lines with a common end-point.

The research literature also indicates that students have difficulty in grasping the multifaceted nature of the concept of angle. Several studies pointed out that students often harbor many misconceptions, conceive an erroneous angle representation and have difficulty learning this concept in the school. For example, many students believe that the size of an angle depends on the length of its sides (Mitchelmore, 1998; Munier \& Merle, 2009; Clements \& Burns, 2000; Keiser, 2004), and they also have difficulty when trying to understand about angles with measures of $0^{\circ}, 180^{\circ}$, and $360^{\circ}$ (Keiser, 2004). They get confused recognizing right angles in 
different orientations (Mitchelmore, 1998). In Indonesia, several researches noted that geometry is one of the hardest topics for students to learn. They also often have difficulty in learning mathematics topics that involve their spatial visualization and reasoning (for example, see Revina, Zulkardi, Darmawijoyo, \& van Galen, 2011). Soedjadi (1991; as cited in Fauzan, 2002) found that many students have difficulties to determine whether an angle is a right angle or not. The misunderstandings that students hold about the concept of angle from an early age can be a crucial learning issue for them because these misconceptions will continue to exist until they learn geometry in the higher level. Furthermore, they will never get the real picture of the concept and they will lack understanding about how the concept of angle is represented and used in everyday life situations.

This study deals with a problem regarding the teaching and learning of the concept of angle in the primary school. We hypothesized that visual field activities involving vision and spatial representations could be used as a means to support students' learning development of the concept of angle. The idea of employing vision in the visual field activities is inspired from the research done by Munier \& Merle (2009) and elicited from the notion of didactical phenomenology design heuristic as a means to help students understand certain topics in mathematics.

We designed a four-step instructional sequence involving visual field activities and spatial representations for teaching and learning the concept of angle. The instructional sequence was designed and investigated according to a design research approach. Design research is a type of research that allows researchers to develop instructional activities and analyze the actual process of students' learning and mental activities when they participate in the instructional activities as constituted in the natural setting of a classroom. The aim of this study is to contribute to the development of a local instructional theory for the concept of angle. The main research question is: how can visual field activities and spatial representations support the development of students' understanding of the concept of angle?

\section{Theoretical Background}

\subsection{The Multifaceted Concept of Angle}

It has been established that angle is a multifaceted concept. Therefore, making a definition of angle becomes a difficult process because all definitions have limitations in describing the concept by emphasizing one facet more heavily than others (Keiser, 2004). Henderson and Taimina (2005; cited by Fyhn, 2007) define angle based on the three different perspectives: angle as geometric shape, angle as dynamic motion (angle as movement) and angle as measure.

In ancient history, some of the Greek geometers tried to define angles. In that time, most of the definitions of angle were included in one of these three categories: a relation, a quality, or a quantity (Keiser, 2004). A famous book in the history of geometry is the one written by Euclid titled Element. According to the definition of angle that Euclid presented in book I of the Elements, it seems that he thought of an angle as the space in between two lines. Freudenthal (1973) then explains Euclid's definition of angle:

Euclid defines the angle as an inclination of lines (even curves were admitted); he meant halflines, because otherwise he would not be able to distinguish adjacent angles from each other... Euclid does not know zero angles, nor straight and bigger than straight lines... Euclid compares, adds and subtracts angles... Euclid takes the liberty of adding angles beyond two or even four right angles; the result cannot be angles according to the original definitions (pp. 476-477).

Proclus and others (Keriser, 2004) also criticized Euclid's definition of angle by arguing that if an angle is only one relationship between two rays, it seems to contradict with the fact that many angles exist for one inclination. For instance, a $90^{\circ}$ angle can have the same form of lines as a $270^{\circ},-270^{\circ},-450^{\circ}$, and $630^{\circ}$ angle.

According to the explanation above, it can be concluded that even the mathematicians in the past were struggling with defining the concept of angle. This historical review of the concept of angle provides some important factors to consider when we think of the struggle students have in learning this concept in the classroom. Furthermore, considering the multifaceted concept and definition of angle from the historical perspective will provide an insight for the researcher when designing a sequence of activities that seek to deal with the most common obstacles and conceptions of the students in learning the concept of angle.

\subsection{Angle Comprehension and Misunderstandings}

Many studies pointed out that children's conceptual understanding about the concept of angle needs to be investigated due to several misconceptions and misunderstandings that exist in their thinking when dealing with that concept in the geometry classroom (e.g. Mitchelmore \& White, 2000; Clements \& Burns, 2000; Keiser, 2004; Munier \& Merle, 2009). One of the possible reasons why students' learning of the concept of angle is 
complicated is that angle is indeed a difficult concept for children to understand. There are many different definitions of angles which vary in their emphases and take different meanings depending on the mathematical situation at hand (Keiser, 2004).

Many studies also found that students who learn the concept of angle in the traditional teaching methods tend to think that the length of the sides affects the size of angle (Mitchelmore \& White, 1998; Munier \& Merle, 2009). Lehrer, Jenkins, and Osana (Munier \& Merle, 2009) reported in their longitudinal studies that the misconception children have in making judgments about angles based on the length of the sides did not diminish during the three years of study. The study conducted by Berthelot and Salin (Munier \& Merle, 2009) also revealed that three-quarters of all pupils cannot make sense of the concept of angle unless it is presented in the primitive, schoolbook form, and that children have trouble recognizing an angle as a subfigure of another figure (p. 1865).

\subsection{Pendidikan Matematika Realistik Indonesia Approach}

The concept of angle is closely related to the real world situation. Mitchelmore (1997) studied children's informal knowledge of physical angle situations and revealed as a conclusion that children had an excellent informal knowledge of angle situations such as turn, slopes, crossings, bends, rebounds, and corners. Introducing the concept of angle from a real world situation such as using visual field activities is the main concern of this study. In this study, we investigated an approach that focuses on the process in which the concept of angle emerges from the students' understanding of visual field activities and spatial representations. This is also in line with the objective of the Pendidikan Matematika Realistik Indonesia (PMRI) approach - the Indonesian version of Realistic Mathematics Education (RME), in which an instructional sequence is aiming to foster the emergence of formal mathematical knowledge of students. Thus, the PMRI approach as an adaptation of RME in Indonesia becomes a domain specific design heuristic underlying the development of the instructional activities as well as a framework to understand the children's thinking in learning the concept of angle.

PMRI is inspired by the philosophy of RME that was developed not only to implement a new way of teaching and learning mathematics but also to achieve social transformation within Indonesia (Sembiring, Hadi \& Dolk, 2008). Several researches have been conducted implementing PMRI approach and employing Indonesian contexts in many schools in Indonesia (Zulkardi, 2002). RME itself has been mostly determined by Freudenthal's (1997) view of mathematics. For him, students should learn mathematics by mathematizing: both subject matter from reality and their own mathematical activity (Gravemeijer, 1999). Freudenthal sees mathematizing as the core of students' activities in reinventing mathematics. In such an approach, material and visual representations may be used by the students as means of scaffolding and communicating their own ideas while constructing more sophisticated mathematics (Gravemeijer, 2011). However, students are not expected to reinvent all mathematics concepts by themselves. In relation to this, Freudenthal (1991) speaks about guided reinvention in which the emphasis is on the character of the learning process rather than on inventing as such (Gravemeijer, 1999). According to Freudenthal (1973), students should be given the opportunity to experience a similar process as the one which the mathematical concept of angle possible. For the researcher, this implies that a learning route should be mapped out that might allows students to do the process of reinvention of angle concept by themselves. To do so, the researcher starts with envisioning a learning route in which students might engage and develop their thinking and learning as they participate in the instructional sequence designed to achieve the intended learning goal of understanding the concept of angle. This envisioned learning route is called a Hypothetical Learning Trajectory (HLT), as proposed by Simon (1995). He stated that HLT is made up of three components: the learning goal which defines the direction, the learning activities, and the hypothetical learning process - a prediction of how the students' thinking and understanding will evolve in the context of the learning activities. Thus, the HLT consists of a planning of an instructional sequence given in a classroom on a day-to-day basis. The HLT that consists of conjecture about possible learning trajectories of students together with conjectures about possible means that support that learning then is called local instructional theories (Gravemeijer \& Cobb, 2006). The term local relates to a set of instructional sequences for a specific topic, which in this study is the concept of angle.

\section{Method}

\subsection{Participants}

The participants were 43 third-grade students of a public elementary school in Palembang, Indonesia. Five students participated in a pilot experiment aiming to investigate students' pre-existing knowledge and to try out the initial design in order to make some adjustments to the initial Hypothetical Learning Trajectory (HLT). The other 38 students participated in the teaching experiment. The group of five students and the group of 38 students were both from the same school, but from different classes. 


\subsection{Research Design}

This study employed a design research as an appropriate approach for achieving the research aim. Design research encompasses three phases: developing a preliminary design, conducting the teaching experiment, and carrying out the retrospective analysis (Gravemeijer, 2004). We chose this approach of design research for at least two reasons. The first is that this study is interested not only to investigate whether the students' experience in the visual field activities and spatial representations tasks could support their learning of the concept of angle, but is also interested in understanding how that learning might take place. The second reason is that a local instruction theory for learning the concept of angle is lacking. This design research has proved itself suitable for developing empirically local instruction theories in the areas of science and mathematics education (Gravemeijer, 2004; Doorman, 2009). The local instruction theory concerns both the process of learning and the means designed to support that learning.

In a design research perspective, the goal of the preliminary design is to formulate a local instructional theory that can be elaborated and refined while conducting the teaching experiment (Gravemeijer \& Cobb, 2006). Accordingly, in this study, the initial idea was inspired and elaborated from studying literature on the history of angle and on recent teaching experiments within this domain which was resulting initial conjectures for the learning of the concept of angle and the means to support that learning. During this literature study, we also started to design the learning activities. This sequence of learning activities including conjecture of students' thinking and strategies was developed and served as the initial HLT. This conjectured HLT was dynamic and could be changed and adjusted to the actual learning process of students during the teaching experiments.

A prototypical instructional sequence was developed in a cyclic process of designing and revising instructional activities. In each cycle, we conducted an anticipatory thought experiment by envisioning how the proposed instructional activities might be used in the classroom, and what students might learn as they participate in them. Actually, there is a reflexive relation between the local instructional theory and the thought and instruction experiments, as the theory gets revised and adjusted under influence of what is learned in the process (Gravemeijer, 2004).

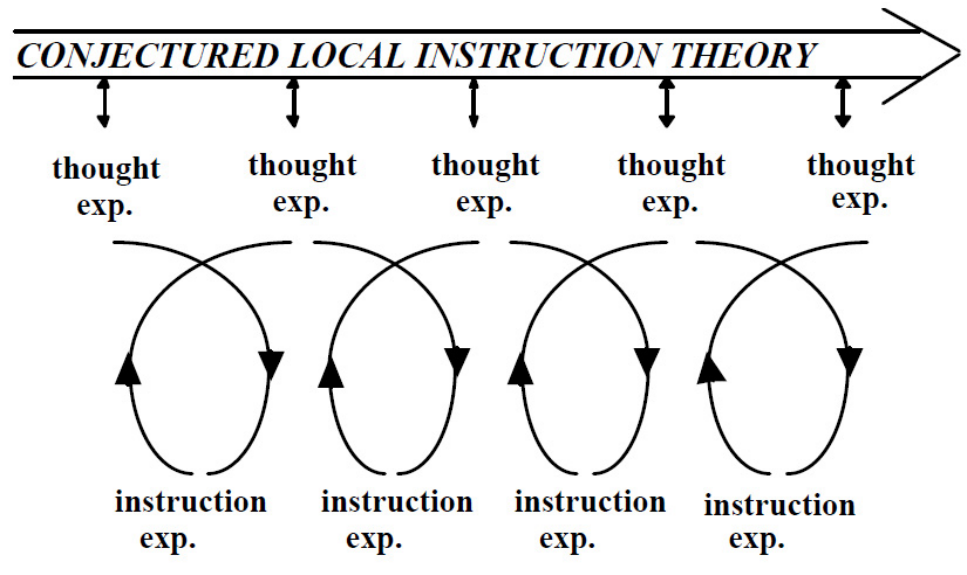

Figure 1. A cumulative cyclic process in design research (Gravemeijer, 2004)

The teaching experiment took place in two third grade classes in one of provincial towns in Indonesia. According to Gravemeijer and Cobb (2006), the purpose of the teaching experiment is both to test and improve the conjectured local instructional theory that is developed in the preliminary phase, and to develop an understanding of how it works. The teaching experiment is also aiming to collect the data in order to answer the research questions. The HLT during the teaching experiment functioned as a guideline for both the teacher and researcher to determine the focus of the teaching, interviewing, and observing.

In the teaching experiment, the sequence of activities developed in the preliminary design was implemented in the classroom within two cycles. The first cycle was conducted as a pilot experiment involved only 5 students in the teaching process. The aim of the pilot experiment was mainly to adjust both the content and the sequence of activities that had been developed and to improve it in order to get a better design for the next cycle of the 
teaching experiment. Then, the second cycle is conducted as the actual teaching process in which the sequence of activities was implemented in the natural classroom environment. The mathematical content of the teaching experiment for these two cycles remained the same under the consideration that the second cycle was the improvement of the first cycle. A reflection about the whole learning process in the end of each lesson that concerns about the strong and the weak points of the lesson was also conducted.

In collecting data, this study involved different types of methods such as interviews, video observations, and student written works. The interview was conducted with all students in the first cycle as a follow up activity of the pre-test. The data from the interview was collected by making a video registration and collecting students' written work. During the teaching experiment in the second cycle, one group of students was video-taped and the whole-classroom discussions were also video-taped. The groups of students were selected with the help of the teacher by using the criteria of clear speech and average capabilities. We used the video-tapes for recording the students' activities in the groups and the whole class discussions. After the teaching experiments, we collected the students' written works and results on an achievement test. These data were analyzed to get the insight of the learning process of the students and to investigate to what extent we had reached the intended content-specific goals.

The data analysis was conducted in the retrospective analysis phase. In this phase, the HLT was used as a guideline and points of references in analyzing of the entire data set collected during the teaching experiment. The HLT was compared with the actual teaching and learning process of students that took place in the classroom. The interpretative framework for understanding the learning process of students was primarily that of RME theory. The description of the analysis was not merely about the instances that support the conjecture, but also the ones that contradicted with it. The conclusion of this analysis was used as the answers for the research questions. The main result is not primarily a design that works, but the rationales of how it works (Gravemeijer \& Cobb, 2006; Cobb et al., 2003).

\subsection{The Instructional Design}

The HLT is a vehicle for planning students' learning of the concept of angle. Thus, the HLT of this study contains an instructional sequence of four steps aimed to reach the goal of the study. All the three components of HLT namely: the learning goals, the description of activity, and the conjectures of students' thinking will be described in each instructional activity. The HLT in the teaching experiment is elaborated as follows:

Table 1. Overview of the HLT for learning the concept of angle

\begin{tabular}{|c|c|c|c|}
\hline Activity & Main Goals & Description of Activity & Conjectures of students' thinking \\
\hline $\begin{array}{l}\text { Now you see it, } \\
\text { now you don't } \\
\text { (Spatial } \\
\text { Representations } \\
\text { Task) }\end{array}$ & $\begin{array}{l}\text { Students } \\
\text { investigate real } \\
\text { situations } \\
\text { involving vision } \\
\text { lines and blind } \\
\text { spots. }\end{array}$ & $\begin{array}{l}\text { The teacher proposes a } \\
\text { worksheet that consists of } \\
\text { three problems depicting the } \\
\text { situation of a cat looking } \\
\text { through a group of mice, } \\
\text { while some mice are hiding } \\
\text { behind of a jar. } \\
\text { - Students discuss in groups } \\
\text { which mice can and which } \\
\text { cannot be seen by the cat and } \\
\text { build their reasoning about it. }\end{array}$ & $\begin{array}{l}\text { Some students will make a } \\
\text { connecting line that goes from the } \\
\text { eye of the cat to the mice. } \\
\text { - Some students will directly point out } \\
\text { the mice beside the jar. } \\
\text { - Some students may realize that there } \\
\text { is a mouse hiding in the first picture } \\
\text { but can be seen in the second } \\
\text { picture. }\end{array}$ \\
\hline
\end{tabular}


Table 2. Overview of the HLT for learning the concept of angle (continued)

\begin{tabular}{|c|c|c|c|}
\hline Activity & Main Goals & Description of Activity & Conjectures of students' thinking \\
\hline $\begin{array}{l}\text { Constructing } \\
\text { vision lines } \\
\text { and blind } \\
\text { spots (Visual } \\
\text { Field } \\
\text { Activities) }\end{array}$ & $\begin{array}{l}\text { Students are } \\
\text { able to construct } \\
\text { vision lines and } \\
\text { blind spots in } \\
\text { two and three } \\
\text { dimensional } \\
\text { representations. }\end{array}$ & $\begin{array}{l}\text { The teacher encourages the } \\
\text { students to conduct visual } \\
\text { field activities constructing } \\
\text { the vision lines of an observer } \\
\text { by using a screen and school } \\
\text { bags. } \\
\text { - Each group of students takes } \\
\text { their turn to be an observer } \\
\text { and to discuss the activity that } \\
\text { they have done. }\end{array}$ & $\begin{array}{l}\text { Some students might realize that the } \\
\text { school bags are aligned as a } \\
\text { representation of the vision lines of } \\
\text { the observer. } \\
\text { - Some students might use ropes to } \\
\text { validate their conjecture about the } \\
\text { forms of the school bags. } \\
\text { - Some students might notice that the } \\
\text { form of the school bags is changed } \\
\text { as the observer moves closer to or } \\
\text { farther away from the screen. }\end{array}$ \\
\hline $\begin{array}{l}\text { Colouring the } \\
\text { blind spots } \\
\text { (Spatial } \\
\text { Rpresentations } \\
\text { Task) }\end{array}$ & $\begin{array}{l}\text { Students are } \\
\text { able to imagine } \\
\text { and visualize the } \\
\text { vision lines and } \\
\text { start to build } \\
\text { their reasoning } \\
\text { in terms of } \\
\text { angle. }\end{array}$ & $\begin{array}{l}\text { The teacher proposes a } \\
\text { worksheet that consists of } \\
\text { several drawings depicting } \\
\text { the situation of the observer } \\
\text { looking through the screen. } \\
\text { - Students with their groups } \\
\text { discuss about the problems } \\
\text { and colour the hidden area (i.e } \\
\text { blind spots) behind the screen } \\
\text { that cannot be seen by the } \\
\text { observer. }\end{array}$ & $\begin{array}{l}\text { - Some students might draw two } \\
\text { perpendicular lines in each side of } \\
\text { the screen and colour the area within } \\
\text { those lines. } \\
\text { - Some students might draw oblique } \\
\text { lines that go through the end point of } \\
\text { the screen but do not go through the } \\
\text { observer. } \\
\text { - Some students might able to draw } \\
\text { the vision lines and colour the blind } \\
\text { spots correctly. }\end{array}$ \\
\hline $\begin{array}{l}\text { Constructing } \\
\text { angle of vision } \\
\text { (Visual Field } \\
\text { Activities) }\end{array}$ & $\begin{array}{l}\text { Students are } \\
\text { able to construct } \\
\text { and draw the } \\
\text { angle of vision } \\
\text { of a different } \\
\text { observer's } \\
\text { position }\end{array}$ & $\begin{array}{l}\text { The teacher encourages the } \\
\text { students to construct the angle } \\
\text { of vision of an observer who } \\
\text { stands infront of the door of } \\
\text { the classroom. } \\
\text { - Students with their group } \\
\text { work on the worksheet } \\
\text { depicting the classroom } \\
\text { ground plan in which they } \\
\text { have to draw the angle of } \\
\text { vision of a different observer. }\end{array}$ & $\begin{array}{l}\text { Some students might draw lines } \\
\text { representing the angle of vision of } \\
\text { the observer that do not touch the } \\
\text { sides of the door. } \\
\text { - Some students might draw lines } \\
\text { representing the angle of vision of } \\
\text { the observer correctly. } \\
\text { - Some students might notice that } \\
\text { there is a position in the classroom } \\
\text { where the observer cannot see it } \\
\text { (blind spots). } \\
\text { - Some students might realize that the } \\
\text { angle of vision of the observer is } \\
\text { changed as the observer moves } \\
\text { closer to or farther away from the } \\
\text { door. }\end{array}$ \\
\hline
\end{tabular}

\section{Results and Discussion}

We first present the result of the pretest to give an impression of the starting point of students' learning process. For the analysis of the lessons we observed the video registrations to investigate what the teacher and students do during the teaching experiment and how the activities could support the students' learning. Then we selected some critical fragments and we compared the HLT specified for particular activities with students' actual learning during the teaching experiment. We also analyzed the written work of students.

\subsection{Meeting 1}

The teacher gave the students a worksheet that consists of three problems about vision lines and blind spots with mice and a cat as the context. These problems are spatial representations of the situation of the cat looking at the mice hiding behind the jar. We hypothesized that by working with these spatial representations, students could develop their mental visualizations when they are trying to imagine and make sense of the situation that they have not seen. These mental visualizations might be seen as the students start to reason and say something about 
the vision of the cat in answering the problems. There is also a possibility that some students draw lines that represent the vision of the cat.

\section{The first problem}

The cat approaches the jar. There are several mice hiding behind the jar. The mice do not walk away from the jar. The cat stops in the position as shown in the picture.
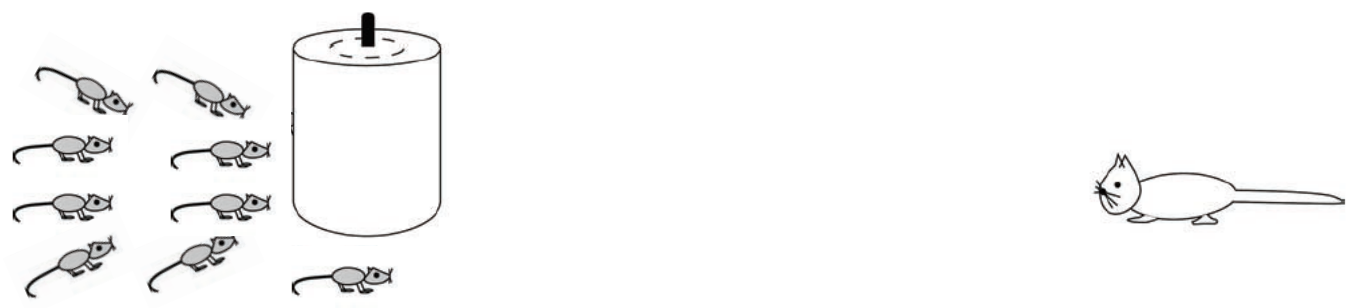

Figure 2. Panoramic drawing of the situation

How many mice can the cat see? Explain and write down your reasoning! (You may make a drawing in the figure).

All students were trying to answer problem 1 by determining the number of mice that the cat can see. Some students argued that the cat can only see the three mice beside the jar because the others are hiding behind the jar. But, also some of them said that the cat can see five mice, three on the left, and two on the right side of the jar (from the perspective of the cat). It shows that students were able to look through the eyes of the cat and recognize that the cat can see some but not all mice directly. The fragment below depict the moment when the researcher asked one of students about their answer and made a drawing of this problem.

Researcher : what does the line mean, Ikhsan? (pointing to the line drawn by the student).

Ikhsan : Its vision, sir. Its vision is impenetrable by only looking to this side (pointing the line that goes to the jar). So, it can only see three (pointing to the three mice besides the jar).

Researcher : Others? (pointing at the other mice).

Ikhsan : Others are invisible because they are behind this (pointing at the jar), behind the jar.

Researcher : Behind the jar.

Students : (laughing)

Reseacher : How many lines are there from the cat? How many lines?

Ihksan : I do not know.

Researcher : How many lines did you draw?

Ikhsan : Three.

Researcher : How many mice did they touch?

Ikhsan : Three.

Reseacher : How about the other mice? (pointing to the other mice).

Ikhsan : : Untouched (by the line), because of this (pointing to the jar).

Reseacher : So?

Ikhsan : they cannot be seen by the cat. Because the cat stops here (pointing to the cat).

The episode above illustrates how a student starts to make sense of the situation in the problem. He could imagine what the vision of the cat looks like as he drew the connecting lines that go from the eye of the cat to the mice. The connecting lines might also serve as a visual proof for him as he pointed out the three mice touched by the lines. It seems that he employed his understanding about vision lines and blind spots as a tool to differentiate between what can or cannot be seen by the cat in the problem. 
Furthermore, most of the students were able to draw lines with different forms that represent the vision of the cat (see Figure 3). Although they were able to make an inferential reasoning for answering the problem, they still make a mistake in their drawing. Probably, their drawing is not the vision lines of the cat, but just a line that proves the cat can see certain mice as they drew those lines for each of the mice.
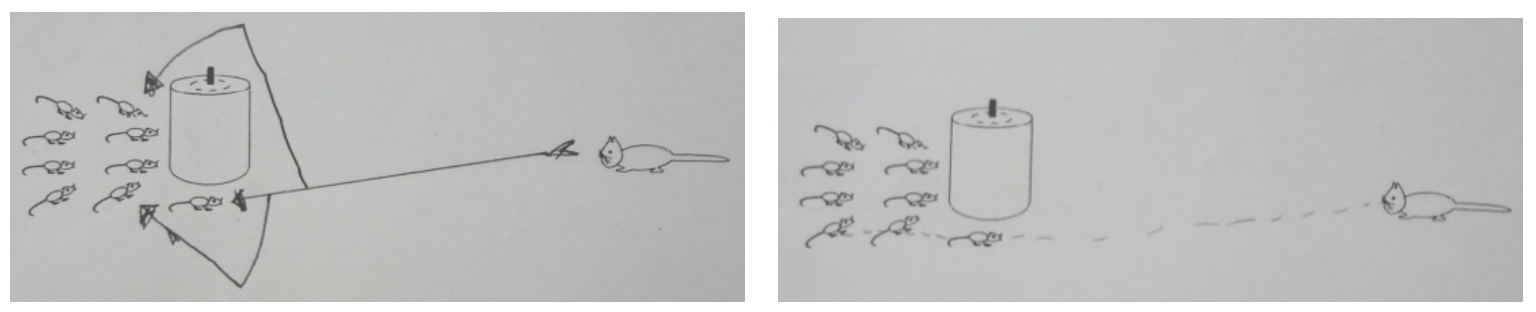

Figure 3. Students' drawing of the vision lines of the cat

The second problem

Below is the top view of the position of the cat and the mice.
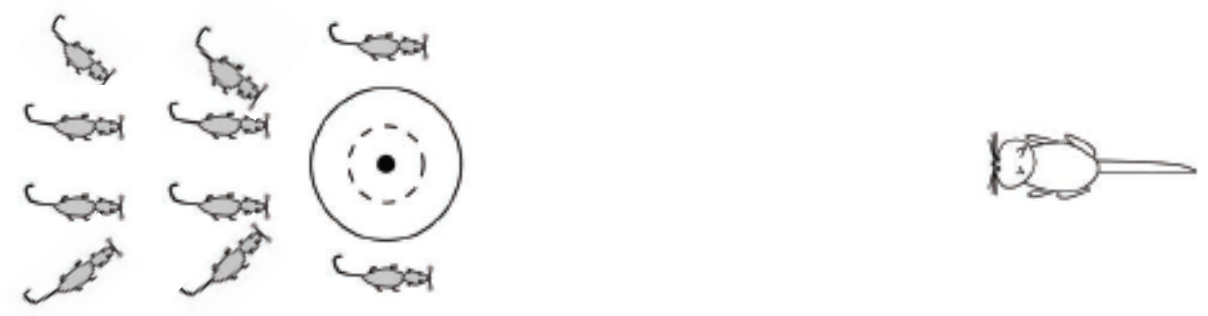

Figure 4. Top view of the situation

Is there any difference in the number of mice that the cat can see in Figure 2 and figure 4? Explain and write down your reasoning! (You may make a drawing in the figure).

In problem 2, students tried to compare the side view and the top view of the situation. Some of the students were able to recognize that these two pictures are different in terms of the number of the mice that the cat can see. In the first drawing, the cat can only see three mice, but in the second drawing the cat can see six mice. Most of them noted that in both drawings the vision of the cat was blocked by the jar. One group explained their reasoning that it is because in the first drawing the cat looked at the mice from the front, whereas in the second drawing the cat looked at the mice from the top view. This students' misunderstanding about the top view may be caused by their lack of understanding about spatial orientations, particularly about the meaning of top view. The students were also struggling in reasoning about their opinion. Perhaps, this is due to the fact that they are not used to having to reason about answers to mathematical problems.

The third problem

Then, several minutes later the cat walks slowly to the jar. The mice stay in the same place.
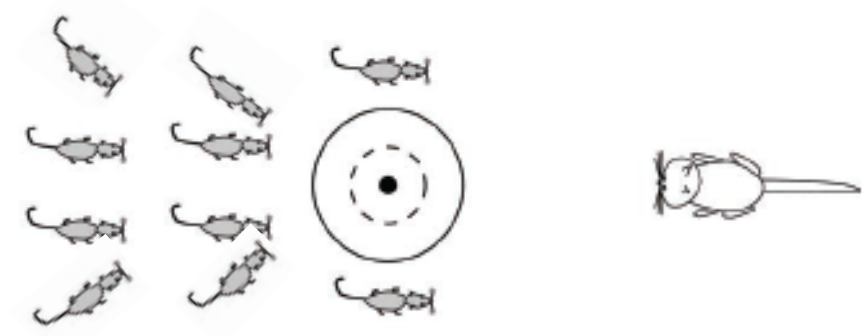

Figure 5. The cat moves closer to the jar (top view) 
One of the students, Andy, said that if the cat comes closer and closer to the mice and they do not walk away, the cat sees less and less mice. Do you agree with Andy? Why/why not? Explain and write down your reasoning in the paper!

In problem 3, some students said that they agreed with Andy's opinion. They argued that as the cat gets closer to the jar, the cat sees less mice. And, if the cat moves very close to the jar, the cat cannot see the mice at all. But, other students have a different opinion and disagree with Andy's opinion. Some of them argued that if the cat gets closer to the jar, the cat should be able to see more mice. Although students' answers were different, it seems that they realized that the movement/position of the cat can influence the number of mice that the cat can see.

Based on the students' results of working on those three problems, we conclude that most of the students had a sense about vision lines and blind spots. They know that the vision of the cat will be different if the cat moves closer to or farther away from the jar. They also tried to make a drawing of the vision of the cat. But, since vision lines cannot be seen in reality, it is understandable that students were struggling to represent these lines in a drawing. Furthermore, they also have struggled because of the perspective of the drawing (top view vs side view) and in top view it is more difficult to draw the vision lines because that needs to go "beyond" the jar. Based on these observations we assumed that by doing physical activities on the playground, constructing the vision lines of the observer, the students might become aware that vision lines, are imaginary lines that extend from the eyes of observer to an object. The vision lines constructed by the students are actually tangent lines, lines that bounded the visible and invisible area. These lines can also be used as a tool to determine what can and cannot be seen by the observer in the experiment. Furthermore, we assumed that when students would construct the vision lines, the notion of angle might emerge since students could see that the vision lines change as the observer moves into different positions. After the first lesson we concluded to conduct such activities in the second lesson.

\section{Meeting 2}

In this second meeting, the teacher encouraged the students to conduct visual field activities of constructing vision lines and blind spots of the observer. The teacher explained to the students that they were going to construct the situation of the cat and mice problem in the last meeting. The teacher put a screen and a chair on the school playground and asked one group of students to act as an observer. The teacher also explained that the screen and the observer are the visualization of the jar and the cat respectively. Then, a student-observer sat in the chair facing the screen and the other students put their school bags in a line behind the screen where they could not be seen, approximately in the middle of the screen.

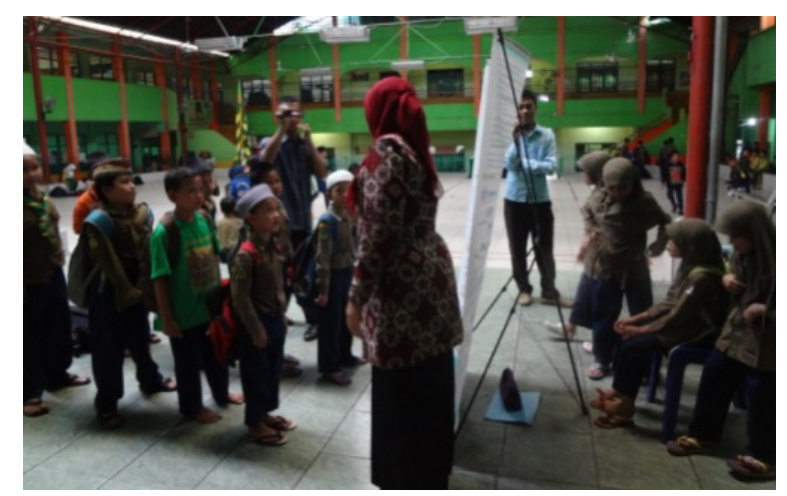

Figure 6 . The teacher encourages students to conduct the physical activities

The students, one pair after another, moved sideways from behind the screen until the observer could see them and then they put their school bag down on the location where they stopped. After doing this activity for several pairs of students, the bags were in two lines behind the screen (diverging from the screen). Then, the teacher posed questions about whether they could predict the next position of school bags. This question is important in order to see whether the students could make a prediction or conjecture on the basis of what they just have done. Furthermore, the students' answers might reveal whether they understand the pattern of the bags and their reasoning why they put it in a certain place instead of another. Most of the students said that they could do that 
and then put their school bags in line with the others. One of the students used her hand to see where she should put the school bags so that it was in line with the others.

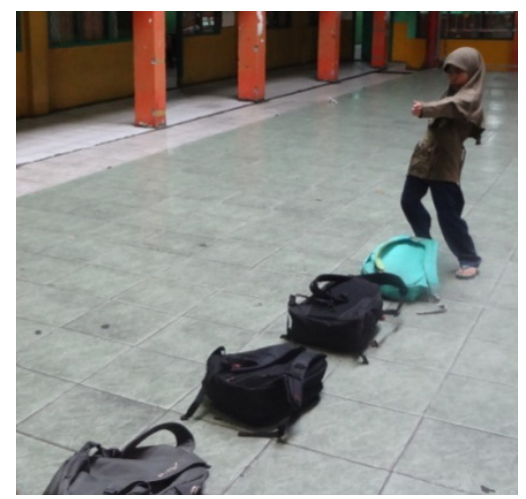

Figure 7. A student's strategy in predicting the next position of the school bag

Students then observed the position of the bags and realized that they were diverging in two lines. The teacher proposed to use a rope to verify their answer by laying out two ropes along the bags. Next, the teacher asked them whether those two lines can meet somewhere. Some students hypothesized that they meet in the observer's place and the teacher followed this opinion by asking them to use the rope and validate their answer. By changing the position of the observer, closer to and further away from the screen, students started to grasp the idea of angle. The concept of angle emerged as the teacher asked questions and guided the students into finding a difference between the observer's closer and farther position from the screen. However, this visual field activity still did not help students in dealing with the most common misconceptions about angle namely that the size of an angle is determined by the length of its arms. Perhaps, that is due to the fact that the angle that students built in this visual field activity is a sector angle (static sense of angle). They were only paying attention to the area of the blind spots in between two ropes. These observations raised the need to add another activity of working with a turning angle (a dynamic sense of angle) that may facilitate students to deal with this misconception.

\section{Meeting 3}

In the third meeting, the teacher presented the four different diagrams depicting the ground plan of the situation in the visual field activities. Then, the students were asked to colour or shade the blind spots (hidden area) for various positions of the observer, as in the visual field activities. In this meeting, we saw that some of the students were able to draw the vision lines and shade the blind spots of different observers. We also found that there are at least four types of drawings from the students.
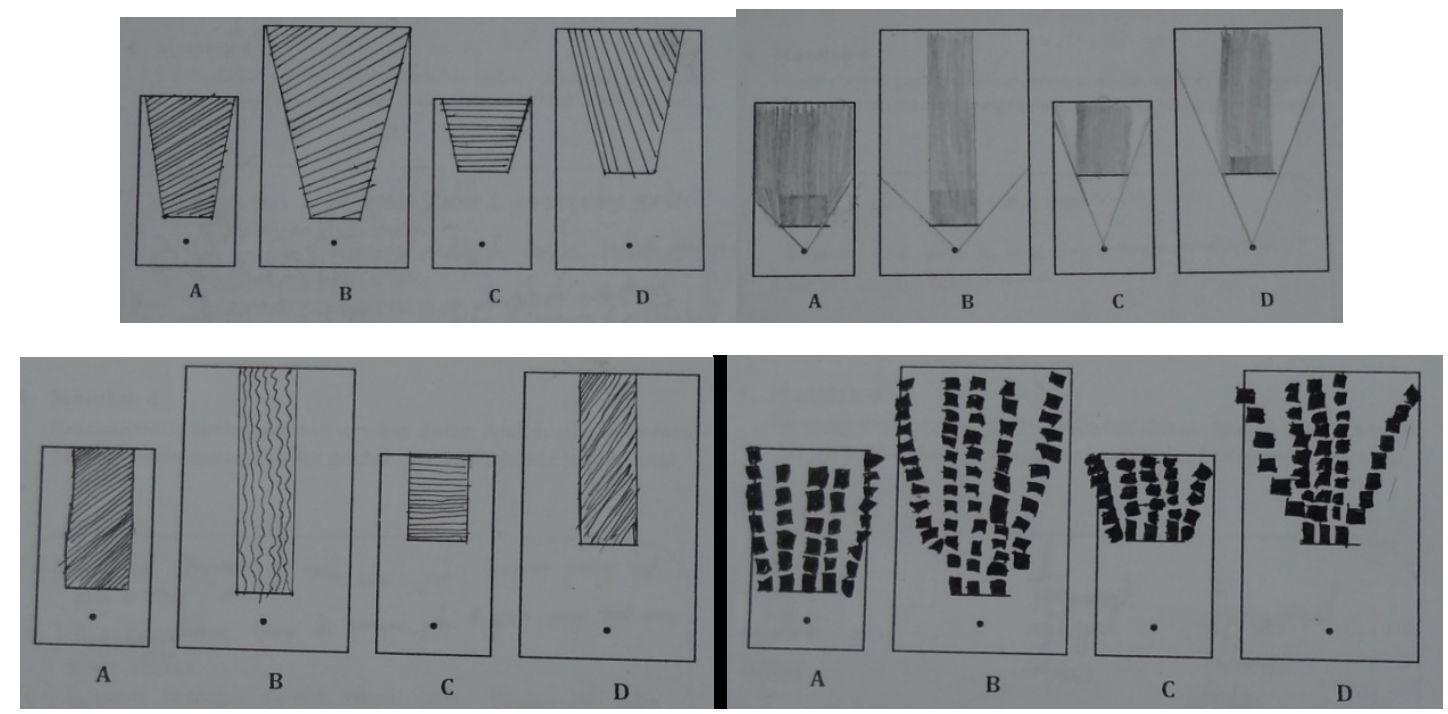

Figure 8. Student's drawing of blind spots 
Although some students answered correctly by drawing the vision lines that went through the end sides of the screen and met in the observer's position, most of the students drew the vertical lines perpendicular to the screen (strip solution), Some drew oblique lines that went through the end points of the screen but did not go through the observer and a few students drew boxes (the representation of the school bags) as the visualization of the visual field activities that they did in the previous meeting. The variety of answers among students shows how difficult it is for them to grasp the concept of vision lines and blind spots.

\section{Meeting 4}

In the fourth meeting, the teacher encouraged the students to construct and draw the angle of vision for different position of the observer. The teacher asked one of students to be an observer standing infront of the door looking into the classroom. Then, two other students constructed the angle of vision by pulling a rope from the student-observer into the classroom where this observer could see half of their bodies. After doing this kind of activity for different positions of the observer (closer to or farther away from the door), the students recognized that as the observer gets closer to the door, the area in between the ropes (i.e. the angle of vision) is getting bigger and vice versa.

Following this activity, the teacher gave the students a worksheet depicting the ground plan of the classroom. The students were then asked to draw the angle of vision of the different observer's position in front of the classroom. Although, the students had done the activity of constructing the angle of vision in the classroom, most of them made an incorrect drawing. It shows that drawing an abstract geometrical concept such as an angle of vision is quite hard for students. They also made a mistake in answering the question which desks that can be or cannot be seen by the observer. So, we may conclude that the students know that the angle of vision is different for different position of observer and it is getting bigger as the observer come closer to the door or vice versa but they are struggling in making a drawing.

In summary, we should stress the importance of visual field activities and spatial representations for teaching and learning the concept of angle. Encouraging students to do these two activities simultaneously seemed to help them in grasping both the static and dynamic sense of the concept of angle. Furthermore, during the lessons the students also developed their understanding about vision lines and blind spots. They could informally reason about vision lines and blind spots involved in the context. However, students at this level still perceived some misconceptions about angles such as the notion that the length of the arms determines the size of angle. Consequently, the next important step in the instructional sequence is to provide activities that allow students to deal with this misconception. Paper fans could be used as bridging activities to allow students to deal with this misconception because an activity with hand-held folding fans would involve the dynamic sense of angle (the inclination of one arm to another). By proposing several kinds of paper fan (big and small), students might realize that the length of the arm does not affect the size of the angle.

\section{Conclusion and Limitation}

The four-step instructional activities we analyzed and discussed, confirmed that students, being allowed to experience both visual field activities and spatial representations tasks, could grasp the static sense of the concept of angle. The notion of angle emerged when students constructed vision lines of different observers in the visual field activities in order to determine the blind spots (hidden area). This study also points out that students can remember what they have experienced in the visual field activities but that this does not mean that they are automatically able to transform their experience into abstract knowledge such as the concept of angle. Although students recognized that the angles that made the blind spots were different as the observer moved closer or farther away to the screen, they still perceived the common misconception that the size of an angle is determined by the length of its arms. This raises the need to improve the design by adding an activity that focuses more on allowing students to validate this misconception.

As an addition, the visual field activities also support social interaction among the students during the learning process. This activity allows students to communicate about a mathematical subject during the learning process. It shows that the learning process not only takes place within individuals themselves, but it also involves the social interactions among them. It is in line with the idea of social and socio-mathematical norms proposed by Yackel and Cobb (1996). Consequently, the teacher plays an important role in facilitating the development of these norms in the classroom. However, because the teacher already gets used to the traditional teaching method of explaining all the materials to the students, she was not familiar to these two norms. This raises the need to help teachers to understand these two norms in order to encourage them to move from perceiving a teacher as the provider of knowledge to a teacher as a knowledgeable orchestrator. 
Although this study was conducted in only one classroom, the instructional idea of this limited study is transferable to other contexts and situations. Other researchers or teachers can use the idea of visual field activities and spatial representations in introducing the concept of angle to third grade students of primary school. However, such activities cannot simply be repeated in other contexts. They always need to be adjusted to local circumstances such as the condition of the classroom and prior knowledge of students if they are to be applied in other situations. Considering the findings of this study, the suggestion for subsequent research is to use visual field activities and spatial representations to intertwine the topic of angle concept and coordinate system.

\section{Acknowledgement}

The authors are thankful to the teacher, Ms Humaro and her students for their participations in this study and also to Mark Uwland for reading the early version of this article. The instructional design central to this paper were elaborated in the course of discussions with Mieke Abels of Utrecht University, The Netherlands. The activities were conducted within the IMPoME program and were funded jointly by DIKTI, Indonesia and NUFFIC NESO, the Netherlands.

Please do not quote without permission. An earlier version of this paper was published in Zulkardi (Ed.). 2013. Proceedings of the $1^{\text {st }}$ South East Asia Design/Development Research Conference. (56-65). Palembang: Sriwijaya University.

\section{References}

Bakker, A., \& van Eerde, D. (2012). An introduction to design-based research for master and $\mathrm{PhD}$ students. In Biker-Ahsbahs, A., Knipping, C., \& Presmeg, N. (Eds.), Doing (qualitative) Research: Methodology and Methods in Mathematics Education. Concept submitted for publication March 15, 2012.

Clements, D. H., \& Burns, B. A. (2000). Students' development of strategies for turn and angle measure. Educational Studies in Mathematics, 41(1), 31-45. http://dx.doi.org/10.1023/A:1003938415559

Cobb, P., Confrey, J., diSessa, A. A., Lehrer, R., \& Schauble, L. (2003). Design experiments in educational research. Educational Researcher, 32, 9-13.

Doorman, M., \& Gravemeijer, K. (2009). Emergent modeling: Discrete graphs to support the understanding of change and velocity. ZDM Mathematics Education, 41, 199-211. http://dx.doi.org/10.1007/s11858-008-0130-z

Fauzan, A. (2002). Applying Realistic Mathematics Education (RME) in Teaching Geometry in Indonesian Primary Schools. Enschede: Doctoral Dissertation, University of Twente.

Freudenthal, H. (1973). Mathematics as an Educational Task. Dordrecht: Kluwer Academic Publishers.

Freudenthal, H. (1991). Revisiting Mathematics Education-China Lectures. Dordrecht: Kluwer Academic Publishers.

Fynn, A. B. (2008). A climbing class' reinvention angles. Educational Studies in Mathematics, 67, 19-35. http://dx.doi.org/ 10.1007/s10649-007-9087-z

Gravemeijer, K. (1994). Developing Realistic Mathematics Education. Utrecht: CD-ß Press / Freudenthal Institute.

Gravemeijer, K. (1999). How Emergent Models May Foster the Constitution of Formal Mathematics. Mathematical Thinking and Learning, 1(2), 155-177. http://dx.doi.org/10.1207/s15327833mt10102_4

Gravemeijer, K. (2004). Local Instruction Theories as Means of Support for Teachers in Reform Mathematics Education. Mathematical Thinking and Learning, 6(2), 105-128. http://dx.doi.org/10.1207/s15327833mt10602_3

Gravemeijer, K. (2011). How concrete is concrete. Indonesian Mathematical Society Journal on Mathematics Education, 2(1), 1-14.

Gravemeijer, K., \& Cobb, P. (2006). Design research from the learning design perspective. In Van den Akker, J., Gravemerijer, K., McKenney, S., \& Nieveen, N. (Eds.), Educational Design Research. London: Routledge.

Health, T. L. (1956). The thirteen Books of Euclid's Elements (vol 1). New York, NY: Dover Publications.

Keiser, J. M. (2004). Struggles with developing the concept of angle: Comparing sixth-grade students' discourse to the history of the angle concept. Mathematical Thinking and Learning, 6(3), 285-306. http://dx.doi.org/10.1207/s15327833mt10603_2 
Matos, J.(1990). The historical development of the concept of angle. The Mathematics Educator, 1(1), 4-11. Version digital available at http://math.coe.uga.edu/TME/Issues/v01n1/2matos.pdf

Mitchelmore, M., \& White, P. (1998). Development of angle concepts: A framework for research. Mathematics educational Research Journal, 10(3), 4-27. http://dx.doi.org/10.1007/BF03217055

Mitchelmore, M., \& White, P. (2000). Development of angle concepts by progressive abstraction and generalization. Educational Studies in $\quad$ Mathematics, $209-238$. http://dx.doi.org/10.1023/A:1003927811079

Mitchelmore, M. (1997). Children's informal knowledge of physical angle situations. Learning and Instruction, 7(1), 1-19. http://dx.doi.org/10.1016/S0959-4752(96)00007-2

Munier, V., \& Merle, H. (2009). Interdisciplinary mathematics-physics approaches to teaching the concept of angle in elementary school. International journal of Science Education, 31(14), 1857-1895. http://dx.doi.org/ 10.1080/09500690802272082

Revina, S., Zulkardi, Darmawijoyo, \& van Galen, F. (2011). Spatial visualization tasks to support students' spatial structuring in learning volume measurement. Indonesian Mathematical Society Journal on Mathematics Education, 2(2), 127-146.

Sembiring, R. K., Hadi, S., \& Dolk, M. (2008). Reforming mathematics learning in Indonesian classroom through RME. ZDM Mathematics Education, 40, 927-939. http://dx.doi.org/ 10.1007/s11858-008-0125-9

Simon, M. A. (1995). Reconstructing mathematics pedagogy from a constructivist perspective. Journal for Research in Mathematics Education, 26, 114-145.

Van den Akker, J., Gravemeijer, K., McKenney, S., \& Nieveen, N. (Eds.). (2006). Educational Design Research. London: Routledge.

Yackel, E., \& Cobb, P. (1996). Sociomathematical norms, argumentation, and autonomy in mathematics. Journal for Research in Mathematics Education, 27(4), 458-477.

Zulkardi, Z. (2002). Developing a Learning Environment on Realistic Mathematics Education for Indonesian Students Teachers. Enschede: Doctoral Dissertation, University of Twente.

\section{Copyrights}

Copyright for this article is retained by the author(s), with first publication rights granted to the journal.

This is an open-access article distributed under the terms and conditions of the Creative Commons Attribution license (http://creativecommons.org/licenses/by/3.0/). 